\title{
Why fossil fuel producer subsidies matter
}

https://doi.org/10.1038/s41586-019-1920-x

Received: 20 November 2018

Accepted: 22 October 2019

Published online: 5 February 2020

\author{
Peter Erickson ${ }^{1 *}$, Harro van Asselt ${ }^{2}$, Doug Koplow ${ }^{3}$, Michael Lazarus ${ }^{1}$, Peter Newell ${ }^{4}$, \\ Naomi Oreskes ${ }^{5} \&$ Geoffrey Supran ${ }^{5}$
}

Arising from: J. Jewell et al. Nature https://doi.org/10.1038/nature25467 (2019)
Around the globe, governments have pledged to remove support for coal, oil and gas, noting that such fossil fuel subsidies "undermine efforts to deal with climate change" by keeping greenhouse gas emissions higher than they otherwise would be ${ }^{1}$. Jewell et al. ${ }^{2}$ used results of integrated assessment models to infer that eliminating subsidies would yield "limited emission reductions...except in energy-exporting regions", and described the emission reduction benefits as "small". This characterization is potentially misleading, and here we use a simple, sector-specific model to show how the emission reductions from producer subsidy reform could be more material than Jewell et al. suggest ${ }^{3}$. Fossil fuel producer subsidies delay a low-carbon transition in ways both material and political, and they deserve greater attention and transparency in global modelling analyses, as well as in policy-making.

The study by Jewell et al. ${ }^{2}$ provides important findings related to fossil fuel subsidy removal. Using a synthesis of five Integrated Assessment Models (IAMs), they find that subsidy removal could reduce global emissions by 0.5 to 2 gigatonnes $(\mathrm{Gt})$ of carbon dioxide $\left(\mathrm{CO}_{2}\right)$ by $2030^{2}$. Jewell et al. characterize these global emission reductions as "unexpectedly small", while noting that they would largely occur within a few energy-exporting countries and regions (Russia, the Middle East and Latin America) ${ }^{2}$.

We argue that the emissions reductions from subsidy removal are not small. By contrast, $0.5-2 \mathrm{Gt} \mathrm{CO}_{2}$ amounts to roughly one quarter of the energy-related emission reductions pledged by all countries under the Paris Agreement ( $4-8 \mathrm{Gt} \mathrm{CO}_{2}$ ), all from a single policy approach that also comes with strong fiscal and other environmental benefits ${ }^{4}$. This scale of emission reductions should not necessarily be surprising or unexpected: few policy analysts hope that any single instrument can deliver reductions at the scale needed to meet climate goals.

Moreover, we argue that the impact of subsidy removal on emissions is likely to be more substantial than Jewell et al. find ${ }^{2}$, particularly when considering support for fossil fuel producers in high-income countries. Although their approach uses common IAM techniques, it does not adequately capture investment dynamics in the supply of new fossil fuels, and therefore misses a major pathway for subsidy reform to affect $\mathrm{CO}_{2}$ emissions. Specifically, their approach does not consider how the timing of producer subsidies (concentrated early in an investment lifetime) and the higher effective discount rates of investors (as compared with society) affect investment decisions to bring on new supplies of oil.

Oil provides more of the world's energy than any other fuel, and exploration and development of supplies remain robust ${ }^{5}$. The model in ref. ${ }^{2}$ of producer subsidies to oil distributes regional subsidy totals equally to all oil fields-both new and already-producing fields-in each region, proportionate to annual output. However, that is often not how subsidies to oil producers work. Instead, governments frequently target subsidies more towards new capital investment than ongoing production. By lowering upfront cash flow requirements, government subsidies boost project investment metrics (such as rate of return or net present value), which leads producers to drill more new wells than they would otherwise. This locks in higher future fossil fuel production and thus also higher future consumption and greenhouse gas emissions ${ }^{6}$.

Using the example of one type of subsidy for investment-accelerated depreciation of new capital investment-we illustrate how oil subsidies could have a bigger effect on global $\mathrm{CO}_{2}$ emissions than in Jewell et al.'s analysis ${ }^{2}$. This particular form of support, exemplified by the intangible drilling cost (IDC) subsidy in the United States, allows companies to quickly write down capital investments that would otherwise depreciate more gradually, providing a boost to cash flow at the beginning of a project.

The IDC subsidy is underappreciated in Jewell et al.'s analysis ${ }^{2}$ because they value it only at the reported value of about US $\$ 0.20$ per barrel (all dollar prices herein refer to 2016) ${ }^{7}$. This reflects the reduction in cash flow to the United States Treasury that results from the delay in annual tax payments. But whereas the USA government may be almost indifferent whether it receives tax revenues this year or the next, oil company investors are not, because they can use that cash flow to accelerate new investment.

If the IDC were valued not on a nominal cash basis but instead on a present value basis, using investor discount rates of $10 \%$ to $20 \%$, the subsidy would make it substantially easier to invest in new oil fields, decreasing the breakeven oil price of new projects by US $\$ 4$ to $\$ 7$ per barrel (Table 1).

Changes in breakeven economics of this scale could have a substantial effect on global oil market price dynamics and consumption. This would especially be the case if subsidy removal were to render uneconomic many of the new projects on course to be developed before 2030. This outcome could well arise, since the USA has a substantial fraction (more than 40\%) of the new oil projects that can be produced by 2030 (Extended Data Fig. 1). Other producers with substantial new supplies planned, such as $\mathrm{Canada}^{8}$ and Norway ${ }^{9}$, also offer accelerated depreciation of new oil capital investments.

Table 1 estimates how the global oil market may respond to removal of the accelerated depreciation subsidies, based on a simple oil market model (see Methods). As shown, in the low-oil-price world featured by Jewell et al. ${ }^{2}$, the effect of removing the depreciation subsidy to producers could reduce global oil consumption by 440 to 770 million barrels in 2030.

Yet the previous analysis by Jewell et al. ${ }^{2}$ includes only a very small fraction of this effect. They do not report this result, but we estimate it to be roughly 21 million barrels (Table 1 , column A).

We therefore believe that, in their low oil price case, Jewell et al. missed a reduction in global $\mathrm{CO}_{2}$ emissions from oil combustion on the order of 200 to 300 million tons $\mathrm{CO}_{2}$ that could result from the removal of a single type of subsidy common in the USA and other oilproducing countries.

The actual outcome on net global $\mathrm{CO}_{2}$ emissions from all fuels is likely to be somewhat lower because coal or gas might substitute for some 
Table 1 | Removing subsidies that accelerate write-down of capital investment reduces global oil consumption

\begin{tabular}{|c|c|c|c|c|}
\hline & \multirow{2}{*}{$\begin{array}{l}\text { (A) Subsidy valued on cash basis, } \\
\text { as in United States government } \\
\text { source used by OECD and ref. }^{2}\end{array}$} & \multicolumn{3}{|c|}{ Subsidy valued on present value basis at given investor discount rates } \\
\hline & & $\begin{array}{l}\text { (B) Rate common in } \\
\text { academic literature }\end{array}$ & $\begin{array}{l}\text { (C) Rate common in } \\
\text { industry studies }\end{array}$ & $\begin{array}{l}\text { (D) Higher-risk rate (if weakened investor } \\
\text { climate or higher-risk fields) }^{10}\end{array}$ \\
\hline & & $10 \%$ & $15 \%$ & $\mathbf{2 0 \%}$ \\
\hline \multicolumn{5}{|c|}{ Effect of subsidy on economics of new oil projects } \\
\hline $\begin{array}{l}\text { Effect on projects' breakeven price } \\
\text { (US\$ per barrel) }\end{array}$ & 0.20 & 4.20 & 5.80 & 7.30 \\
\hline \multicolumn{5}{|c|}{ Market effects of subsidy removal for high-oil-price case in 2030} \\
\hline $\begin{array}{l}\text { Increase in global oil price } \\
\text { (US\$ per barrel) }\end{array}$ & 0.07 & 1.40 & 1.90 & 2.40 \\
\hline $\begin{array}{l}\text { Decrease in global oil consumption } \\
\text { (millions of barrels) }\end{array}$ & 4 & 76 & 110 & 130 \\
\hline $\begin{array}{l}\text { Decrease in global } \mathrm{CO}_{2} \text { emissions } \\
\text { from oil (millions of tonnes of } \mathrm{CO}_{2} \text { ) }\end{array}$ & 1 & 30 & 42 & 52 \\
\hline \multicolumn{5}{|c|}{ Market effects of subsidy removal for low-oil-price case in 2030} \\
\hline $\begin{array}{l}\text { Increase in global oil price } \\
\text { (US\$ per barrel) }\end{array}$ & 0.13 & 2.80 & 3.90 & 4.90 \\
\hline $\begin{array}{l}\text { Decrease in global oil consumption } \\
\text { (millions of barrels) }\end{array}$ & 21 & 440 & 620 & 770 \\
\hline $\begin{array}{l}\text { Decrease in global } \mathrm{CO}_{2} \text { emissions } \\
\text { from oil (millions of tonnes of } \mathrm{CO}_{2} \text { ) }\end{array}$ & 8 & 180 & 250 & 310 \\
\hline \multicolumn{5}{|c|}{$\begin{array}{l}\text { These estimates of the effect of subsidies on projects' breakeven prices (first row) are calculated on a present value basis, as the production-weighted averages across nearly } 800 \text { discovered oil } \\
\text { fields in the United States (see Methods). By contrast, Jewell et al. }{ }^{2} \text { value the fast depreciation subsidy only on a cash basis, spread across all fields; while they do not report the value of this sub- } \\
\text { sidy in their analysis, we estimate it from the same primary sources they used to be about US } \$ 0.20 \text { per barrel (column A), as described further in the Methods. We estimate the market effects of } \\
\text { removing these subsidies using a simple oil market model, at three different investor discount rates (columns B to D), all of which are on a nominal basis (no deduction for inflation). We assume } \\
\text { that not-yet-developed USA oil projects are higher up the oil cost curve in } 2030 \text { (as is oil from other countries that also have a corresponding accelerated depreciation subsidy, like Canada } \\
\text { or Norway), such that increases in the breakeven prices of these fields could well have a direct effect on long-term prices and consumption levels. We also assume here that subsidy removal } \\
\text { begins immediately (in 2019), whereas Jewell et al. assume subsidy phase-out starts in } 2020 \text { and is completed in } 2030 \text {. However, producer subsidy removal is not subject to the same concerns } \\
\text { as consumer subsidy removal-namely equity and locked-in consumer behaviour-and thus would not need to be phased in so gradually. }\end{array}$} \\
\hline
\end{tabular}

of the lost oil consumption, though concurrent removal of subsidies for these fuels would minimize this effect. IAM models, like those used by Jewell et al. ${ }^{2}$, are well suited to evaluating these interactions. Yet the scale on which $\mathrm{CO}_{2}$ emissions from oil have potentially been underestimated-equivalent to $10 \%$ to $60 \%$ of the reported global effect ${ }^{2}$ due to removal of all subsidies ( 0.5 to $2 \mathrm{Gt} \mathrm{CO}_{2}$ in 2030)-suggests that oil producer subsidies deserve greater attention and transparency in global modelling analyses.

The investment-oriented approach to modelling subsidies used here and the broader, average cost-curve approach of ref. ${ }^{2}$ are not incompatible. Fossil fuel supply in IAMs could be modelled using an investment approach and vintage capital structure, as is often applied to power plants that have upfront costs and default lifetimes ${ }^{10}$. In such an approach, new oil deposits would also be modelled as prospective investments, as demonstrated here, using realistic discount rates of $10 \%$ to $20 \%$ that are common in the oil industry ${ }^{11}$.

In fact, subsidies may have an even more important role than we can quantify here. Extra company revenue resulting from subsidies can be used not only for more drilling, but also for product promotion, political activities and other efforts that fortify the industry's incumbent status. Subsidies also have a symbolic effect, in that they communicate the normative position that this industry and its activities are beneficial for society as a whole and, therefore, should be encouraged. Jewell et al. ${ }^{2}$ disregard these socio-political effects when downplaying the value of removing fossil fuel subsidies.

The economic, political and symbolic effects of subsidies reinforce each other ${ }^{12}$. For example, subsidies can beget more subsidies, with new, long-lived fossil fuel infrastructure in turn (1) requiring further subsidization down the line to continue operating ${ }^{13,14}$, and (2) yielding beneficiaries who will vigorously defend continued subsidization ${ }^{15}$. Since there can be a revolving door between government staff and subsidy recipients, public officials may find it even harder to pass strong climate and energy policies ${ }^{16}$. Indeed, the most troubling impact and legacy of fossil fuel subsidies may be the political barriers that fossil fuel producers have erected in recent decades against decarbonization efforts ${ }^{17,18}$.

Rapid low-carbon transitions consistent with the guardrails of the Paris Agreement require dramatically reduced fossil fuel production ${ }^{19}$. Subsidies to fossil fuel companies pose formidable financial, institutional and political obstacles to this transition, impeding the efficacy of greenhouse gas emission reduction strategies. The apparent small dollar values of producer subsidies in official, government-approved ledgers, and the limited emissions impact suggested by global models such as those used by Jewell et al. ${ }^{2}$, can be misleading. The actual impacts, particularly when one considers their social and political effects, are far greater.

Methods are in the Supplementary Information to this Matters Arising Comment.

\section{Reporting summary}

Further information on research design is available in the Nature Research Reporting Summary linked to this paper.

\section{Data availability}

The authors declare that data supporting the calculations in columns B through to D of Table 1 are included as Supplementary Information. The raw data analysed by the authors for Extended Data Fig. 1 are available from Rystad Energy in their UCube database, but restrictions apply to the availability of these data, which were used under license for the referenced study, and so are not publicly available. Raw data are available from the authors upon reasonable request and with permission of Rystad Energy.

\section{Code availability}

No custom code or mathematical algorithms were used to generate results reported in this paper. The entirety of the oil market model is provided as equation (1) in the Methods. 
1. Leaders of the G2O G2O Leaders' Statement: The Pittsburgh Summit. https://www.oecd. org/g2O/summits/pittsburgh/ (Organisation for Economic Co-operation and Development, 2009).

2. Jewell, J. et al. Limited emission reductions from fuel subsidy removal except in energyexporting regions. Nature 554, 229-233 (2018)

3. Erickson, P., Down, A., Lazarus, M. \& Koplow, D. Effect of subsidies to fossil fuel companies on United States crude oil production. Nat. Energy 2, 891-898 (2017).

4. Merrill, L., Gerasimchuk, I., Wooders, P. \& Bassi, A. Fossil Fuel Subsidy Reform Research Suggests Emission Reductions Equivalent to at Least a Quarter of the Commitments Countries Made at Paris. https://www.iisd.org/gsi/subsidy-watch-blog/fossil-fuel-subsidyreform-research-suggests-emission-reductions-equivalent (International Institute for Sustainable Development, 2018)

5. IEA World Energy Investment 2018 (Organisation for Economic Co-operation and Development, 2018).

6. Erickson, P. \& Lazarus, M. Global emissions: new oil investments boost carbon lock-in. Nature 526, 43 (2015).

7. OECD Companion to the Inventory of Support Measures for Fossil Fuels 2015 (Organisation for Economic Co-operation and Development, 2015).

8. Sawyer, D. \& Stiebert, S. Fossil Fuels-At What Cost? Government support for upstream oil activities in three Canadian provinces: Alberta, Saskatchewan, and Newfoundland and Labrador https://www.iisd.org/library/fossil-fuels-what-cost-government-supportupstream-oil-activities-three-canadian-provinces (International Institute for Sustainable Development, 2010)

9. Erickson, P. \& Down, A. How Tax Support For The Petroleum Industry Could Contradict Norway's Climate Goals https://www.sei.org/publications/tax-petroleum-norwaysclimate-goals/ (Stockholm Environment Institute, 2017).

10. Iyer, G. C. et al. Improved representation of investment decisions in assessments of $\mathrm{CO}_{2}$ mitigation. Nat. Clim. Chang. 5, 436-440 (2015).

11. Fattouh, B., Poudineh, R. \& West, R. Energy Transition, Uncertainty, and the Implications of Change in the Risk Preferences of Fossil Fuels Investors https://www. oxfordenergy.org/publications/energy-transition-uncertainty-implications-changerisk-preferences-fossil-fuels-investors/?v=7516fd43adaa (Oxford Institute for Energy Studies, 2019).

12. Seto, K. C. et al. Carbon lock-in: types, causes, and policy implications. Annu. Rev. Environ. Resour. 41, 425-452 (2016).

13. Sovacool, B. K. Reviewing, reforming, and rethinking global energy subsidies: towards a political economy research agenda. Ecol. Econ. 135, 150-163 (2017).

14. Newell, P. \& Johnstone, P. The political economy of incumbency. In The Politics of Fossil Fuel Subsidies and their Reform (eds van Asselt, H. \& Skovgaard, J.) 66-80 (Cambridge Univ. Press, 2018).
15. Koplow, D. Global energy subsidies: scale, opportunity costs, and barriers to reform. In Energy Poverty (eds Halff, A., Sovacool, B. K. \& Rozhon, J.) 316-337 (Oxford Univ. Press, 2014).

16. Oreskes, N. \& Conway, E. M. Merchants of Doubt: How a Handful of Scientists Obscured the Truth on Issues from Tobacco Smoke to Global Warming (Bloomsbury Press, 2010).

17. Geels, F. W., Tyfield, D. \& Urry, J. Regime resistance against low-carbon transitions: introducing politics and power into the multi-level perspective. Theory Cult. Soc. 31, 21-40 (2014).

18. Supran, G. \& Oreskes, N. Assessing ExxonMobil's climate change communications (1977-2014). Environ. Res. Lett. 12, 084019 (2017).

19. Rogelj, J. et al. Mitigation pathways compatible with $1.5^{\circ} \mathrm{C}$ in the context of sustainable development. In Global Warming Of $1.5^{\circ} \mathrm{C}$ : An IPCC Special Report On The Impacts Of Global Warming Of $1.5^{\circ} \mathrm{C}$ Above Pre-Industrial Levels And Related Global Greenhouse Gas Emission Pathways, In The Context Of Strengthening The Global Response To The Threat Of Climate Change, Sustainable Development, And Efforts To Eradicate Poverty Ch. 2 (IPCC, 2018).

20. Erickson, P. Confronting carbon lock-in: Canada's oil sands. SEl discussion brief. https:// www.sei.org/publications/confronting-carbon-lock-canadas-oil-sands/ (Stockholm Environment Institute, 2018).

Acknowledgements P.E. and M.L. thank A. Vogt-Schilb, S. Pye and N. Bauer for discussions about IAM models. P.E. acknowledges funding from the Schmidt Family Foundation.

Author contributions P.E. and M.L. conceptualized the research (with input from H.v.A., D.K., N.O. and G.S.). P.E. carried out the numerical modelling. P.E. wrote and revised the manuscript (with contributions from H.V.A, D.K., M.L., P.N., N.O. and G.S.).

Competing interests The authors declare no competing interests.

\section{Additional information}

Supplementary information is available for this paper at https://doi.org/10.1038/s41586-0191920-x.

Correspondence and requests for materials should be addressed to P.E.

Reprints and permissions information is available at http://www.nature.com/reprints. Publisher's note Springer Nature remains neutral with regard to jurisdictional claims in published maps and institutional affiliations.

(c) The Author(s), under exclusive licence to Springer Nature Limited 2020 


\section{Matters arising}

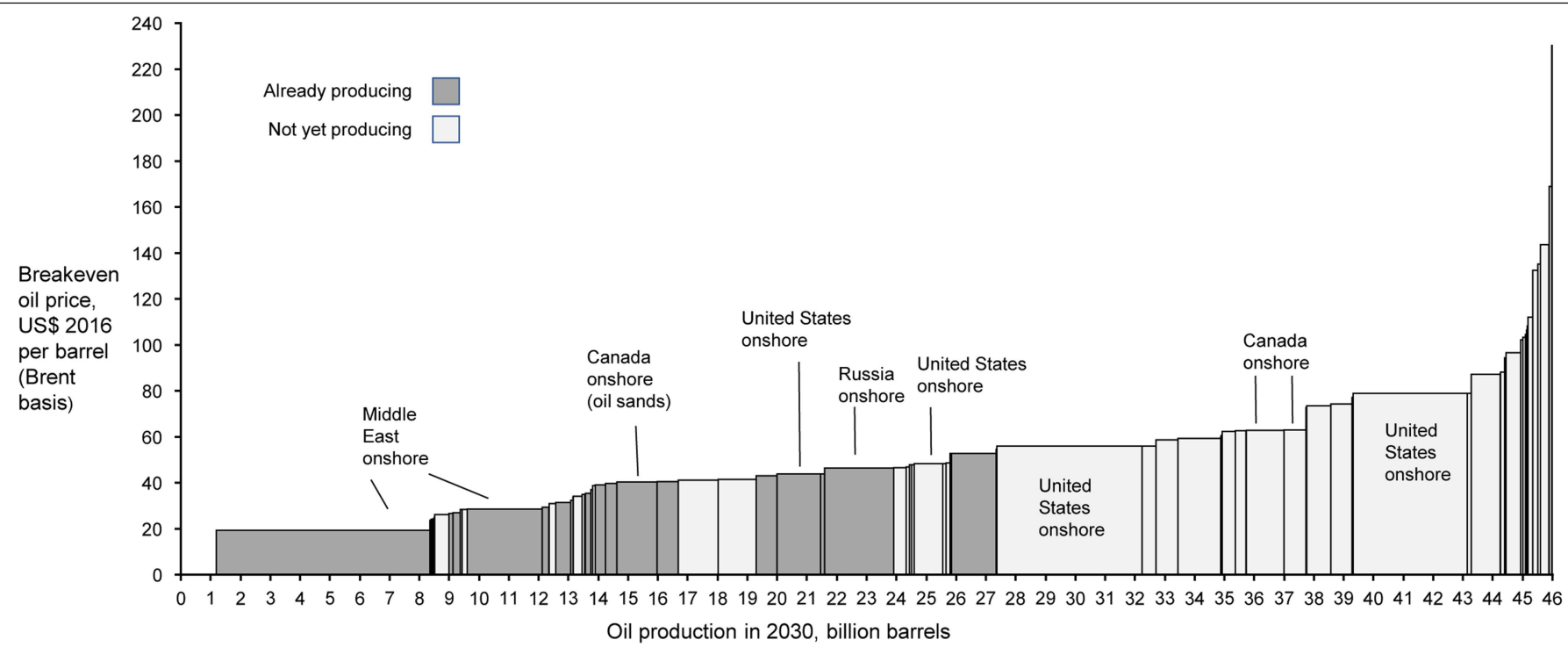

Extended Data Fig. 1 | Cost curve of world oil production in 2030. The cumulative supply of oil in 2030 is shown for increasing oil price. Most blocks (64 of 80) in this cost curve represent a combination of a particular stage of development (one of four) in eight major world regions (the continents plus the Middle East and Russia minus Antarctica), whether onshore or offshore.
Further (16) blocks represent the USA or Canada, since they are major new sources of oil (about $41 \%$ and $7 \%$ of all regions that are not yet producing oil). The figure is adapted from figure 1 in ref. ${ }^{20}$ and based on data from Rystad Energy (see 'Data availability' section). 


\section{Reply to: Why fossil fuel producer subsidies matter}

https://doi.org/10.1038/s41586-019-1921-9

Published online: 5 February 2020

\author{
Jessica Jewell ${ }^{1,2,3 *}$, Johannes Emmerling ${ }^{5,6}$, Vadim Vinichenko ${ }^{2,3}$, Christoph Bertram ${ }^{7}$, \\ Loïc Berger ${ }^{5,6,8}$, Hannah E. Daly ${ }^{9}$, Ilkka Keppo ${ }^{10}$, Volker Krey ${ }^{11,12}$, David E. H. J. Gernaat ${ }^{13,14}$, \\ Kostas Fragkiadakis ${ }^{15}$, David McCollum ${ }^{16}$, Leonidas Paroussas ${ }^{15}$, Keywan Riahi ${ }^{11,17}$, \\ Massimo Tavoni ${ }^{5,6,18}$ \& Detlef van Vuuren ${ }^{13,14}$
}

Replying to: P. Erickson et al. Nature https://doi.org/10.1038/s41586-019-1920-x (2020)
In 2009, the $G 20$ countries pledged to phase out fossil fuel subsidies ${ }^{1}$. Our original Letter highlighted that about $95 \%$ of subsidies go to consumers and two-thirds are in the Middle East, Russia and Latin America². We also found the largest emission reductions from subsidy removal would occur in those three regions, where low oil prices provided a unique political opportunity and the reforms would harm fewer poor people. In the accompanying Comment ${ }^{3}$, Erickson et al. argue that we downplay the impact of subsidy removal and the effect of subsidies for oil producers, such as the USA's intangible drilling cost (IDC) scheme. Here we show large variations in such schemes and estimate their impact to be within the range of the sensitivity analysis from our original article. The USA IDC may represent a unique political opportunity for producer subsidy reform, but reforming such schemes may be counterproductive in countries where they are applied in tandem with high taxes for oil production.

We estimated that emission reductions from subsidy removal would be between $2-8 \%$ and $3-15 \%$ of those required by 2030 to achieve the $1.5^{\circ} \mathrm{C}$ and $2^{\circ} \mathrm{C}$ targets. We called this "unexpectedly small” because these estimates contrast with sweeping statements that subsidy

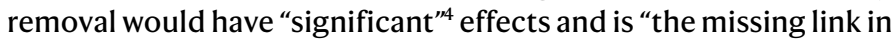
the fight against climate change" ${ }^{\prime 5}$. Yet we agree with Erickson et al. ${ }^{3}$ that given the immensity of the climate challenge, these numbers are notable and are certainly not an argument against subsidy reform.

Erickson et al. ${ }^{3}$ estimate the size and effect of the USA's IDC scheme, which allows accelerated depreciation of drilling costs, essentially tax deferrals for oil producers. Their approach is different from ours in how subsidies are defined and measured. In our original Letter ${ }^{2}$, we used government inventories ${ }^{6-8}$ for our central estimate, because these are the very subsidies that governments have pledged to remove. Erickson et al. ${ }^{3}$ consider any regulation that makes oil production more profitable to be a subsidy even if it does not involve net transfers from the government. This leads them to use data not from government inventories of subsidies but from analysing oil production economics. Thus, Erickson et al. ${ }^{3}$ analyse the hypothetical cash flow for 800 oil fields in the USA and calculate the effect of the IDC scheme on the breakeven price of individual projects-we call this the 'effective subsidy rate'. They then assess the global impact of similar schemes by assuming all oil producers worldwide benefit from the same effective subsidy rate as in the USA.

Global IAMs can greatly benefit from such data if they are parameterized for long-term global scenarios. The first set of parameters defines how accelerated depreciation affects the effective subsidy rate. This depends on a project's breakeven price, discount rate, share of capital costs, the national tax regime, and the design of the accelerated depreciation scheme, all of which vary widely across countries and over time (Methods). To determine whether Erickson et al.'s results ${ }^{3}$ would affect our original findings ${ }^{2}$, we developed a discounted cash flow model to analyse the effective subsidy rate for the USA IDC and from accelerated depreciation schemes for three additional countries with diverse institutional arrangements and geographies (Methods).

In the case of the USA, our model provides results similar to those of Erickson et al. ${ }^{3}$ for the 2016 case, but the 2017 tax cut reduced the effective subsidy rate by about half and the recent fall in the cost of North American tight oil reduced it by another $30 \%$ (Table 1, Methods). The effective subsidy rates from accelerated depreciation schemes in Canada, Norway and Russia under a range of plausible breakeven prices are between two and ten times smaller than the USA 2016 case. Using this range, we estimate the global effective subsidy rate from accelerated depreciation schemes to be US\$0.3-1.9 per barrel [using central assumptions, as described in the Methods, the value is US\$1.0; central values are shown herein in square brackets] (US dollar prices herein refer to 2016; Table 1).

The uncertainty in estimating production subsidies is well known ${ }^{6,9,10}$. That is why, in our original Letter ${ }^{2}$, we included a sensitivity analysis using an alternative estimate of production subsidies (including an alternative calculation of the USA's IDC scheme $)^{10}$. Oil production subsidies in that analysis for the low-oil-price scenario were about fifteen times higher than those reported in government inventories ${ }^{2}$. The oil production subsidy rates in that original sensitivity analysis are also generally higher than the effective subsidy rates we estimate for accelerated depreciation schemes (column C of Table 1 ).

The second step in the analysis by Erickson et al. ${ }^{3}$ is to estimate the effect of accelerated depreciation schemes on global oil consumption

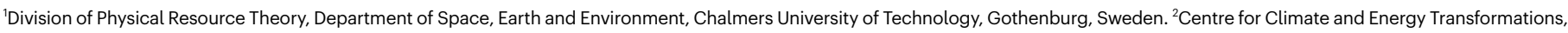
University of Bergen, Bergen, Norway. ${ }^{3}$ Department of Geography, Faculty of Social Sciences, University of Bergen, Bergen, Norway. ${ }^{4}$ Risk and Resilience Program, International Institute for Applied Systems Analysis, Laxenburg, Austria. ${ }^{5} \mathrm{RFF}-\mathrm{CMCC}$ European Institute on Economics and the Environment, Milan, Italy. ${ }^{6}$ Fondazione Centro Euromediterraneo sui Cambiamenti Climatici, Lecce, Italy. ${ }^{7}$ Potsdam Institute for Climate Impact Research, Member of the Leibniz Association, Potsdam, Germany. ${ }^{8}$ IESEG School of Management, CNRS, Université Lille, UMR 9221-LEM, Lille, France. ${ }^{9} \mathrm{MaREI}$, the SFI Research Centre for Energy, Climate and Marine, Environmental Research Institute, University College Cork, Cork, Ireland. ${ }^{10}$ UCL Energy Institute, University College London, London, UK. "Energy Program, International Institute for Applied Systems Analysis, Laxenburg, Austria. ${ }^{12}$ Industrial Ecology and Energy Transitions Programmes, Norwegian University of Science and Technology (NTNU), Trondheim, Norway. ${ }^{13}$ Copernicus Institute for Sustainable Development, University of Utrecht, Utrecht, The Netherlands. ${ }^{14}$ PBL

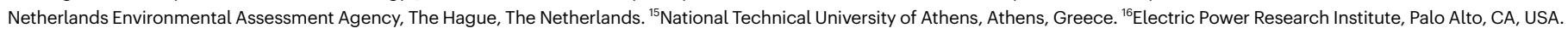
${ }^{17}$ Institute of Thermal Engineering, Graz University of Technology, Graz, Austria. ${ }^{18}$ Department of Management, Economics and Industrial Engineering, Politecnico di Milano, Milan, Italy. *e-mail: jewell@chalmers.se 


\section{Table 1 | The effect of oil production subsidies on producer costs and global oil consumption}

\begin{tabular}{|c|c|c|c|c|}
\hline & \multicolumn{2}{|c|}{$\begin{array}{l}\text { IAM analysis of all producer subsidies in Jewell et al. }{ }^{2} \\
\text { (low-oil-price scenario) }\end{array}$} & \multicolumn{2}{|c|}{$\begin{array}{l}\text { Discounted cash flow model of accelerated depreciation schemes } \\
\text { (10\% discount rate except for final row; see Methods) }\end{array}$} \\
\hline & $\begin{array}{l}\text { (A) Main estimate of production } \\
\text { subsidies from ref. }\end{array}$ & $\begin{array}{l}\text { (B) Higher production } \\
\text { subsidies from refs. }\end{array}$ & $\begin{array}{l}\text { (C) Variations in tax rates, capital cost, } \\
\text { accelerated depreciation schemes, } \\
\text { breakeven prices and elasticities (our analysis) }\end{array}$ & (D) Erickson et al. ${ }^{3}$ \\
\hline \multicolumn{5}{|c|}{ Effective production subsidy rate (US\$ per barrel) } \\
\hline USA & 0.6 & 2.4 & $\begin{array}{l}1.9(2019 \text { case }) \\
4.9(2016 \text { case })\end{array}$ & $4.2(2016$ case $)$ \\
\hline Other regions & $\begin{array}{l}\text { Canada } 1.1 \\
\text { Europe } 0.4 \\
\text { Russia O } \\
\text { MENA O }\end{array}$ & $\begin{array}{l}\text { Canada } 1.5 \\
\text { Europe } 2.2 \\
\text { Russia } 5.2 \\
\text { MENA } 2.3\end{array}$ & $\begin{array}{l}\text { Canada 0.5-1.4 [0.9] } \\
\text { Norway 0.9-2.0 [1.5] } \\
\text { Russia 0.9-2.1 [1.6] } \\
\text { Saudi Arabia and Nigeria 0 }\end{array}$ & \\
\hline Global & 0.2 & 2.6 & $0.3-1.9[1.0]$ & \\
\hline
\end{tabular}

Change in global oil extraction or consumption (millions of barrels per year) for the low-oil-price scenario

Change in extraction due to higher production subsidy estimate 590

Variation due to effective subsidy rate using elasticities in Erickson et l $^{3}$ and $10 \%$ discount $\quad 30-200$ [110] rate

Variation due to elasticity assumptions ${ }^{11,12}$ using central effective subsidy rate and 10\% 20-140 [90] discount rate

Variation due to discount rates using central effective subsidy rate and elasticities in Erickson et al. ${ }^{3}$ In column (C), discount rates vary from $7.5 \%$ to $20 \%$ and in column (D) from

$90-150[130]$

$10 \%$ to $20 \%$ (Methods). In both cases, the discount rate for the central estimate is $15 \%$.

Columns $A$ and $B$ contain estimates of all oil production subsidies from our original article ${ }^{2}$. In our sensitivity case, the subsidy rate and its effect on oil production is higher than under acceler-

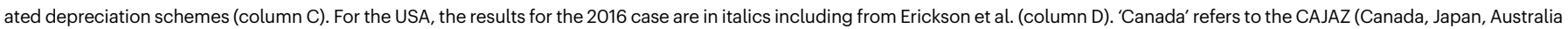
and New Zealand) region whose oil production is dominated by Canada (over 98\%). 'MENA' refers to the Middle East and North Africa region.

with a simple oil market model. Their calculation is sensitive to supply and demand elasticities that are highly uncertain (Methods). They use a single value for demand elasticity and a single value for supply elasticity for each oil price. A range of supply and demand elasticities from previous studies that used the same simple oil market model $\mathrm{l}^{11,12}$ changes the results by almost by an order of magnitude even under the same effective subsidy rate (Table 1, Methods).

In the sensitivity analysis from our original article, we estimated that a more than tenfold increase in oil production subsidies would increase oil extraction by 590 million barrels per year (Table 1). The higher production subsidies (including all production subsidies, not just oil) would increase emission reductions from subsidy removal by 0.3 gigatonnes of carbon dioxide per year in 2030 , which is about $13 \%$ higher than the main estimate of the model used for that sensitivity analysis, or about $1 \%$ of the emission reduction required by 2030 to achieve the $1.5^{\circ} \mathrm{C}$ or $2^{\circ} \mathrm{C}$ target (Methods).

The final parameter affecting the effective subsidy rate is the discount rate, which Erickson et al. ${ }^{3}$ assume varies between $10-20 \%$. The upper end of this range is speculative because discount rates for the oil sector have generally varied between $9 \%$ and $11 \%{ }^{13}$ (Methods). Table 1 shows our results using a discount rate of $10 \%$, but our conclusions are robust over the full range in Erickson et al. ${ }^{3}$ : a $20 \%$ discount rate increases the global effective subsidy rate to US\$0.4-2.7 [1.4] per barrel (Methods).

This exchange highlights the importance of improving IAM parameters by incorporating new data. Such data are more meaningful to global long-term IAMs if it is clear whether and how they are applicable beyond a single country at a single point in time. The generalizability of such data can be improved if they extend to a wider and more representative sample ${ }^{9,10}$, which IAMs can use, as illustrated by the sensitivity analysis in our original article. Finally, these data should be up-to-date and transparent about uncertainties, including those arising from differences in policy environments.

Although the effect of accelerated depreciation schemes can be incorporated into IAMs by adjusting the effective subsidy rate, we also agree with Erickson et al. ${ }^{3}$ that IAMs should better represent oil and gas infrastructure in the same way as they model the vintage structure of the power sector ${ }^{14}$. Another promising avenue would be to depict oil and gas investments using a real options ' wait and see' approach ${ }^{15}$ and to model price formation in the oil market ${ }^{16}$ more realistically. These improvements may either dampen or amplify the effects of subsidies in IAMs, depending on whether infrastructural inertia, 'wait and see' behaviour, and strategic markets are more or less responsive to producer cost signals than in today's IAMs.

We also strongly agree with Erickson et al. ${ }^{3}$ that the social and political impacts of subsidy removal should always be examined in tandem with their emission impacts. However, it is time for social scientists to go beyond listing various negative effects of subsidies which are well documented in the literature and clearly extend beyond economics ${ }^{17-20}$ and instead identify opportunities and pathways for reform. That is why, in our original article, we complemented energy and emissions analysis with a discussion of the socio-political impacts of subsidies to identify a political opportunity for reform in oil- and gas-exporting countries under low oil prices where reducing consumption subsidies would affect fewer poor people, relieve squeezed government budgets and lead to the largest emission reductions.

A lesson from our original article is that the environmental and sociopolitical impacts of and obstacles to consumer subsidy reform vary between countries. This is almost certainly the case for producer subsidies as well. In the USA, the original rationale (energy security and uncertainty in oil drilling) for the IDC is outdated, and the scheme now does little more than confer an unfair advantage on a polluting, privately owned and profitable industry. Reforming this scheme is complicated by the political clout of the industry, but at least its public benefits and endpoint are clear.

However, such subsidies are much more difficult to identify, much less reform, in countries like Norway and Russia where oil producers pay very high taxes-reaching over $70 \%$ on profits. These taxes are a major source of government revenue used to fund public services. Would reforming accelerated depreciation schemes in these contexts also mean tax reductions for the industry? Would the endpoint be to bring the oil industry in line with the rest of the economy, something clearly not desirable either socially or environmentally? And if not, what would be the goal and the strategy for reform? 
Generalizing insights from the USA to the whole world is misleading both in terms of science and policy. Finding effective strategies to meet the Paris Agreement requires a detailed understanding of how oil production and other carbon-intensive sectors are embedded in national socio-political and economic contexts.

\section{Reporting summary}

Further information on research design is available in the Nature Research Reporting Summary linked to this paper.

\section{Data availability}

The authors declare that the data supporting the calculations are available in the Methods or from publicly available sources cited in the Methods.

\section{Code availability}

No custom code or algorithms were developed for the discounted cash flow results reported in this paper.

1. Joint Report By IEA, OPEC, OECD And World Bank On Fossil-fuel And Other Energy Subsidies: An Update Of The G2O Pittsburgh And Toronto Commitments https://www. oecd.org/env/49090716.pdf (IEA, OPEC, OECD and World Bank, 2011).

2. Jewell, J. et al. Limited emission reductions from fuel subsidy removal except in energyexporting regions. Nature 554, 229-233 (2018).

3. Erickson, P. et al. Why fossil fuel producer subsidies matter. Nature https://doi. org/10.1038/s41586-019-1920-x (2020)

4. Intergovernmental Panel on Climate Change (IPCC). Technical Summary In Climate Change 2014: Mitigation of climate change. Contribution of Working Group III to the Fifth Assessment Report of the Intergovernmental Panel on Climate Change (eds Edenhofer, O. et al.) 33-107 (Cambridge Univ. Press, 2014).

5. Friends of Fossil Fuel Subsidy Reform. Briefing Note July 2015: Fossil Fuel Subsidy Reform and the Communiqué. http://fffsr.org/wp-content/uploads/2015/07/ffrs-communique briefing-note.pdf (Friends of Fossil Fuel Subsidy Reform, 2015).

6. OECD OECD Companion to the Inventory of Support Measures for Fossil Fuels 2015 https://www.oecd.org/publications/oecd-companion-to-the-inventory-of-supportmeasures-for-fossil-fuels-2015-9789264239616-en.htm (OECD, 2015)

7 IEA World Energy Outlook 2016 https://webstore.iea.org/world-energy-outlook-2016 (International Energy Agency, 2016).

8. IEA World Energy Outlook 2014 https://webstore.iea.org/world-energy-outlook-2014 (International Energy Agency, 2014).

9. Bast, E., Doukas, A., Pickard, S., Burg, L. Van Der \& Whitley, S. Empty Promises: G2O Subsidies to Oil, Gas And Coal Production. https://www.odi.org/sites/odi.org.uk/files/odiassets/publications-opinion-files/9957.pdf (Overseas Development Institute and Oil Change International, 2015).
10. Gerasimchuk, I. et al. Zombie energy: climate benefits of ending subsidies to fossil fuel production. Working paper. https://www.iisd.org/sites/default/files/publications/zombieenergy-climate-benefits-ending-subsidies-fossil-fuel-production.pdf (International Institute for Sustainable Development, Global Subsidies Initiative, and Overseas Development Institute, 2017).

11. Erickson, P., Down, A., Lazarus, M. \& Koplow, D. Effect of subsidies to fossil fuel companies on United States crude oil production. Nat. Energy 2, 891-898 (2017).

12. Erickson, P. \& Lazarus, M. Impact of the Keystone XL pipeline on global oil markets and greenhouse gas emissions. Nat. Clim. Chang. 4, 778-781 (2014).

13. Damodaran, A. Cost Of Equity And Capital (Updateable) http://people.stern.nyu.edu/ adamodar/New Home_Page/datafile/wacc.htm (2019).

14. Johnson, N. et al. Stranded on a low-carbon planet: implications of climate policy for the phase-out of coal-based power plants. Technol. Forecast. Soc. Change 90, 89-102 (2015).

15. Compernolle, T., Welkenhuysen, K., Huisman, K., Piessens, K. \& Kort, P. Off-shore enhanced oil recovery in the North Sea: the impact of price uncertainty on the investment decisions. Energy Policy 101, 123-137 (2017)

16. Ansari, E. \& Kaufmann, R. K. The effect of oil and gas price and price volatility on rig activity in tight formations and OPEC strategy. Nat. Energy 4, 321-328 (2019).

17. Victor, D. G. The Politics of Fossil-Fuel Subsidies https://papers.ssrn.com/sol3/papers. cfm?abstract_id=1520984 (Global Subsidies Initiative and International Institute for Sustainable Development, 2009).

18. Inchauste, G. \& Victor, D. G. The Political Economy of Energy Subsidy Reform Public Sector Governance (World Bank, 2017).

19. Sovacool, B. K. Reviewing, reforming, and rethinking global energy subsidies: towards a political economy research agenda. Ecol. Econ. 135, 150-163 (2017).

20. Lockwood, M. Fossil fuel subsidy reform, rent management and political fragmentation in developing countries. New Polit. Econ. 20, 475-494 (2015).

Acknowledgements This work was supported by the Research Council Norway under the Contractions project ("Analyzing past and future energy industry contractions: towards a better understanding of the flip-side of energy transitions") under grant agreement number 267528/E10. We thank A. Cherp for discussions on the discounted cash flow model.

Author contributions The change in composition (removal of Nawfal Saadi and addition of Hannah Daly) and order of the author list in this Matters Arising compared to the original Letter reflects the contributions to the Matters Arising Reply, which relied on a discounted cash flow model and additional empirical research in order to validate the assumptions and sensitivity analysis from the original article. J.J., J.E., V.V. and C.B. wrote the Reply with contributions from L.B., H.D., I.K., V.K., D.E.H.J.G., K.F., D.M, L.P., K.R., M.T. and D.V. The numerical model was conceived and designed by J.J. and V.V. and implemented by V.V. The results were analysed by J.J. and V.V.

Competing interests The authors declare no competing interests.

Additional information

Supplementary information is available for this paper at https://doi.org/10.1038/s41586-019 1921-9.

Correspondence and requests for materials should be addressed to $\mathrm{J}$.

Reprints and permissions information is available at http://www.nature.com/reprints. Publisher's note Springer Nature remains neutral with regard to jurisdictional claims in published maps and institutional affiliations.

(c) The Author(s), under exclusive licence to Springer Nature Limited 2020 